\title{
IMPLEMENTASI PERATURAN DAERAH KABUPATEN DHARMASRAYA NOMOR 19 TAHUN 2007 TENTANG PENGOLAHAN DAN PENGUSAHAAN PERTAMBANGAN DAN ENERGI DALAM PERSPEKTIF SIYASAH DUSTURIYAH
}

\author{
Nadia $^{1}$, Khairina ${ }^{2}$ \\ ${ }^{1}$ Institut Agama Islam Negeri (IAIN) Batusangkar \\ e-mail: nadiaazza03@gmail.com \\ ${ }^{2}$ Institut Agama Islam Negeri (IAIN) Batusangkar \\ e-mail: khairinainong@gmail.com
}

\begin{abstract}
Implementasi Peraturan Daerah Kabupaten Dharmasraya nomor 19 tahun 2007 tentang pengolaban dan pengusahaan pertambangan dan energi Masib banyak para penambang liar melakukan usaha pertambangan yang tidak sesuai dengan peraturan yang berlaku sehingga memberikan dampak yang buruk bagi lingkungan sekitar dan daerah aliran sungai. Penelitian ini adalah penelitian lapangan (field research), yaitu penelitian yang dilakukan di Nagari Siguntur Kecamatan Sitiung Kabupaten Dharmasraya. Sumber data dari penelitian ini terdiri dari sumber data primer dan sumber data sekunder. Penelitian ini menggunakan teknik pengumpulan data dengan melakukan wawancara yang dilakukan oleh penulis dengan Bapak. Kepala Bagian Hukum Kantor Bupati Kabupaten Dharnasraya, Bapak Kepala Bidang Penataan dan Penegakan Hukum Lingkungan hidup Kabupaten Dharmasraya, dan unsur masyarakat di Nagari Siguntur dan dokumentasidisini adalah mengacu pada material (bahan) seperti, Perda Kabupaten Dharmasraya Nomor 19 tahun 2007. Sejumlah besar fakta dan data tersimpan dalam bahan yang berbentuke dokumentasi. Penelitian yang penulis lakukan ditemukan babwa, Implementasi Peraturan Daerah Kabupaten Dharmasraya Nomor 19 Tabun 2007 tentang pengolahan dan pengusahaan pertambangan dan energi tidak, terlaksana dengan baik. Kendala yang dihadapi pemerintah adalah ketika masyarakat mengetahui peraturan yang telah dibuat, dan mereka para penambang liar tidak mengindahkan sosialisasi yang disampaikan Pemerintah Daerah. Kedua pandangansiyasah dusturiyah terhadap implementasi Peraturan Daerah Kabupaten Dharmasraya nomor 19 tabun 2007 dimana kinerja kepemimpinan yang belum memiliki sifat- sifat seorang pemimpin belum dimiliki secara keseluruban.
\end{abstract}

Kata kunci: Implementasi PERDA, Pertambangan Emas Ilegal, Siyasah Dusturiyah.

\section{PENDAHULUAN}

Indonesia merupakan Negara yang kaya akan sumber daya alam termasuk bahan galian pertambangan. Indonesia memiliki ketergantungan tinggi terhadap pemanfaatan bahan galian pertambangan tersebut sebagai modal pembangunan. Pemanfaatannya diatur oleh pemerintah melalui suatu peraturan perundang-undangan. Berdasarkan Undang-Undang Dasar Negara Republik Indonesia Tahun 1945 pada alinea ke IV dijelaskan bahwa tujuan dari Negara Indonesia adalah melindungi segenap Bangsa Indonesia dan seluruh tumpah darah 
Indonesia, memajukan kesejahteraan umum, mencerdaskan kehidupan bangsa dan ikut melaksanakan ketertiban dunia. Sesuai dengan Pasal 33 Ayat (3) Undang -Undang Dasar Negara Republik Indonesia Tahun 1945 menyatakan bahwa "bumi dan air dan kekayaan alam yang terkandung di dalamnya dikuasai oleh negara dan digunakan sebesar-besarnya untuk kemakmuran rakyat".

Pembangunan apabila dikaitkan di Indonesia, pada hakikatnya merupakan suatu proses perubahan yang terus menerus dengan melakukan perbaikan dan peningkatan menuju kearah cita-cita dan tujuan pembangunan nasional diantaranya mewujudkan masyarakat adil dan makmur serta mencerdaskan kehidupan bangsa berdasarkan Pancasila dan UUD 1945. Salah satu agenda usaha negara dalam mewujudkan masyarakat yang adil dan makmur adalah dengan melakukan pemanfaatan hasil bumi dalam berbagai sektor, dalam pemanfaatan bahan tambang khususnya emas.

Bagian dari kekayaan alam yang ada di Indonesia adalah pertambangan. Pertambangan merupakan usaha untuk menggali berbagai potensi-potensi. Sektor pertambangan di Indonesia merupakan salah satu sektor pemasukan devisa besar bagi pendapatan Negara, namun keberadaan kegiatan pertambangan di Indonesia banyak dipersoalkan oleh berbagai lapisan masyarakat secara keseluruhan, khususnya pada pertambangan emas tanpa izin. Penambangan menimbulkan paradoks antara pendapatan dan keuntungan, ketika pemanfaatan lahan tambang tidak dimanfaatkan secara baik dan benar. Sektor pertambangan di Indonesia ini keberadaan kegiatan dan usaha tambang di Indonesia kini banyak dipersoalkan oleh berbagai kalangan dalam implementasinya. Negara sering dihadapkan pada kondisi dilematis antara pemanfaatan optimal dengan kerugian lingkungan dan sosial (Adrian, 2011 :103).

Kegiatan pertambangan sudah sangat berkembang, hasil yang diberikan sangat memberikan keuntungan bagi peningkatan kesejahteraan hidup masyarakat, khususnya bagi para penambang. Meskipun demikian, kegiatan yang menjanjikan ini turut pula membawa dampak yang merugikan bagi manusia dan lingkungan hidup. Kegiatan tersebut tidak dilakukan berdasarkan peraturan yang telah ditetapkan, yaitu kegiatan pertambangan yang dilakukan secara ilegal atau tanpa izin yang dikenal dengan sebutan PETI (Pertambangan Emas Tanpa Izin). Kegiatan usaha tambang telah menimbulkan dampak negatif, maka dalam kegiatan pertambangan perlu adanya pengaturan yang dapat mencegah timbulnya kerusakan dan pencemaran lingkungan (Pipin Syarif, 2012, 15).

Instrument hukum yang dipergunakan oleh pemerintah adalah perizinan. Sebagaimana yang telah diketahui bahwa negara mempunyai hak menguasaiatas bumi, air dan kekayaan alam yang terkandung didalamnya termasuk tambang. Berdasarkan hal tersebut setiap orang yang melakukan kegiatan pertambangan aturan mainnya wajib meminta izin terlebih dahulu dari negara atau pemerintah. Pengertian dari izin tersebut adalah salah satu bentuk pelaksanaan fungsi pengaturan dan bersifat mengendalikan yang dimiliki oleh pemerintah terhadap kegiatan-kegiatan yang dilakukan oleh masyarakat. Pengelolaan pertambangan di Indonesia saat ini kewenangannya diserahkan pada masing-masing daerah yang memiliki potensi sumber dayaalam, seperti yang tercantum dalam Undang-Undang Dasar Negara Republik Indonesia tahun 1945 setelah amandemen mengenai pemerintahan daerah.

Pasal 18 Ayat (5) Undang-Undang Nomor 23 Tahun 2014 tentang Otomi Daerah yang dicantumkan bahwa "Pemerintahan daerah menjalankan otonomi seluas-luasnya, kecuali urusan pemerintahan yang oleh Undang-Undang ditentukan sebagai urusan Pemerintah Pusat". Otonomi daerah itu sendiri adalah hak, wewenang dan kewajiban daerah otonomi untuk mengatur dan mengurus sendiri urusan pemerintahan dan kepentingan masyarakat 
setempat sesuai dengan peraturan perundang-undangan. Setelah adanya amandemen UndangUndang Nomor 23 Tahun 2014 Jo Undang-Undang Nomor 9 Tahun 2015 maka secara resmi Negara memberikan hak otonomi kepada daerah untuk mengurus, mengatur, dan mengelola rumah tangganya sendiri (Adrian, 2011: 241).

Indonesia merupakan Negara yang kaya akan sumber daya alam termasuk bahan galian pertambangan. Indonesia memiliki ketergantungan tinggi terhadap pemanfaatan bahan galian pertambangan tersebut sebagai modal pembangunan. Pemanfaatannya diatur oleh pemerintah melalui suatu peraturan perundang-undangan. Berdasarkan Undang-Undang Dasar Negara Republik Indonesia Tahun 1945 pada alinea ke IV dijelaskan bahwa tujuan dari Negara Indonesia adalah melindungi segenap Bangsa Indonesia dan seluruh tumpah darah Indonesia, memajukan kesejahteraan umum, mencerdaskan kehidupan bangsa dan ikut melaksanakan ketertiban dunia. Sesuai dengan Pasal 33 Ayat (3) Undang -Undang Dasar Negara Republik Indonesia Tahun 1945 menyatakan bahwa "bumi dan air dan kekayaan alam yang terkandung di dalamnya dikuasai oleh negara dan digunakan sebesar-besarnya untuk kemakmuran rakyat".

Pembangunan apabila dikaitkan di Indonesia, pada hakikatnya merupakan suatu proses perubahan yang terus menerus dengan melakukan perbaikan dan peningkatan menuju kearah cita-cita dan tujuan pembangunan nasional diantaranya mewujudkan masyarakat adil dan makmur serta mencerdaskan kehidupan bangsa berdasarkan Pancasila dan UUD 1945. Salah satu agenda usaha negara dalam mewujudkan masyarakat yang adil dan makmur adalah dengan melakukan pemanfaatan hasil bumi dalam berbagai sektor, dalam pemanfaatan bahan tambang khususnya emas. Bagian dari kekayaan alam yang ada di Indonesia adalah pertambangan. Pertambangan merupakan usaha untuk menggali berbagai potensi-potensi. Sektor pertambangan di Indonesia merupakan salah satu sektor pemasukan devisa besar bagi pendapatan Negara, namun keberadaan kegiatan pertambangan di Indonesia banyak dipersoalkan oleh berbagai lapisan masyarakat secara keseluruhan, khususnya pada pertambangan emas tanpa izin. Penambangan menimbulkan paradoks antara pendapatan dan keuntungan, ketika pemanfaatan lahan tambang tidak dimanfaatkan secara baik dan benar. Sektor pertambangan di Indonesia ini keberadaan kegiatan dan usaha tambang di Indonesia kini banyak dipersoalkan oleh berbagai kalangan dalam implementasinya (Adrian, 2011 :103).

Kegiatan pertambangan sudah sangat berkembang, hasil yang diberikan sangat memberikan keuntungan bagi peningkatan kesejahteraan hidup masyarakat, khususnya bagi para penambang. Meskipun demikian, kegiatan yang menjanjikan ini turut pula membawa dampak yang merugikan bagi manusia dan lingkungan hidup. Kegiatan tersebut tidak dilakukan berdasarkan peraturan yang telah ditetapkan, yaitu kegiatan pertambangan yang dilakukan secara ilegal atau tanpa izin yang dikenal dengan sebutan PETI (Pertambangan Emas Tanpa Izin). Kegiatan usaha tambang telah menimbulkan dampak negatif, maka dalam kegiatan pertambangan perlu adanya pengaturan yang dapat mencegah timbulnya kerusakan dan pencemaran lingkungan (Pipin Syarif, 2012, 15).

Instrument hukum yang dipergunakan oleh pemerintah adalah perizinan. Sebagaimana yang telah diketahui bahwa negara mempunyai hak menguasaiatas bumi, air dan kekayaan 
alam yang terkandung didalamnya termasuk tambang. Berdasarkan hal tersebut setiap orang yang melakukan kegiatan pertambangan aturan mainnya wajib meminta izin terlebih dahulu dari negara atau pemerintah. Pengertian dari izin tersebut adalah salah satu bentuk pelaksanaan fungsi pengaturan dan bersifat mengendalikan yang dimiliki oleh pemerintah terhadap kegiatan-kegiatan yang dilakukan oleh masyarakat. Pengelolaan pertambangan di Indonesia saat ini kewenangannya diserahkan pada masing-masing daerah yang memiliki potensi sumber dayaalam, seperti yang tercantum dalam Undang-Undang Dasar Negara Republik Indonesia tahun 1945 setelah amandemen mengenai pemerintahan daerah.

Pasal 18 Ayat (5) Undang-Undang Nomor 23 Tahun 2014 tentang Otomi Daerah yang dicantumkan bahwa "Pemerintahan daerah menjalankan otonomi seluas-luasnya, kecuali urusan pemerintahan yang oleh Undang-Undang ditentukan sebagai urusan Pemerintah Pusat". Otonomi daerah itu sendiri adalah hak, wewenang dan kewajiban daerah otonomi untuk mengatur dan mengurus sendiri urusan pemerintahan dan kepentingan masyarakat setempat sesuai dengan peraturan perundang-undangan. Setelah adanya amandemen UndangUndang Nomor 23 Tahun 2014 Jo Undang-Undang Nomor 9 Tahun 2015 maka secara resmi Negara memberikan hak otonomi kepada daerah untuk mengurus, mengatur, dan mengelola rumah tangganya sendiri (Adrian, 2011: 241).

Pertambangan emas yang tidak memiliki izin banyak bermunculan dan menimbulkan dampak lingkungan serta kerugian terhadap pendapatan Daerah Kabupaten Dharmasraya, oleh karena itu Bupati Dharmasraya mengeluarkan Keputusan Bupati Dharmasraya Nomor: 189.1/153/KPTS-BUP/2011 tentang Pembentukan Tim Penertiban Kegiatan Pertambangan Tanpa Izin (PETI) di Kabupaten Dharmasraya menyebutkan bahwa tugas dan tanggung jawab tim penertiban kegiatan pertambangan tanpa izin (PETI) adalah sebagai berikut:

1. Melakukan pembinaan dan sosialisasi terhadap pelaku penambang PETI.

2. Melaksanakan penertiban dan penindakan terhadap pertambangan tanpa izin (PETI).

3. Bertanggung jawab terhadap penangkapan dan penyitaan barang.

4. Memproses secara hukum pelaku kegiatan PETI tersebut sesuai dengan peraturan yang berlaku.

5. Menyampaikan laporan terhadap hasil kegiatan tim kepada Bupati Dharmasraya melalui Sekretaris Daerah.

Aktifitas penambangan ilegal itu menyebabkan kerusakan daerah aliran sungai (DAS) dan pencemaran air sungai semakin parah, air sungai berubah menjadi keruh dan tidak layak untuk digunakan, terjadi aktivitas penambangan yang mulai dilakukan agak terbuka dan mengunakan mesin-mesin di lahan-lahan pinggir sungai. Sebelumnya masyarakat juga sudah menambang emas hanya saja dilakukan dengan cara tradisional, yaitu mendulang atau mengindang. Cara inilah yang kemudian diperbaharui secara teknis menggunakan mesin dumping yang menyedot pasir mengandung emas. Akibat penyedotan pasir dengan menggunakan mesin, sejumlah cerukan dibagian sungai muncul.

Bagian lain terlihat gundukan material pasir dan aliran sungai yang berubah berwarna coklat keruh. Padahal tak jauh dari lokasi tersebut warga tampak mencuci pakaian dan anakanak kecil mandi di sungai tersebut. Sepanjang Sungai Batanghari, tambang emas di Dharmasraya ini juga beroperasi di anak-anak sungai yang bermuara ke Batanghari seperti Batang Koto balai, Sungai Betung, Kotobesar, Bonjol, Bulang dan Nyunyo. Penambangan juga dilakukan oleh masyarakat yang memiliki tanah ulayat di pinggir anak-anak sungai itu, kadang ada juga yang menyewakan tanah ulayat untuk ditambang. 
Pertambangan emas ilegal telah berdampak buruk pada lingkungan sekitar, seperti keruhnya air sungai, tidak adanya tempat pemandian masyarakat sekitar tepian air sungai, para penambang juga belum memiliki izin untuk melakukan kegiatan tersebut. Sampai sekarang pertambangan emas disepanjang sungai batang hari belum semuanya bisa ditertibkan sehingga diperlukan penertiban yang lebih intensif agar pertambangan emas secara ilegal tidak menjamur di Kabupaten Dharmasraya.

Berdasarkan pandangan hukum Islam mengenai pertambangan ini termasuk ke dalam kajian siyasahdusturiyah. Siyasah dusturiyahadalah hubungan antara pemimpin dan rakyatnya serta lembaga-lembaga yang ada di dalam elemen masyarakat. Objek kajian fikih siyasah dusturiyah meliputi peraturan perundang-undangan yang bersumber dari Al-Qur'an, hadist nabi, kebijakan pemimpin, ijtihad ulama, dan adat kebiasaan suatu negara baik tertulis ataupun tidak tertulis (Djazuli, 2007: 73). Menurut pandangan siyasah tanfidziyyah, yaitu suatu lembaga eksekutif dalam Islam dinyatakan dengan istilah ulil amri dan dikepalai oleh seorang Amir atau Khalifah. Tugas al- sulthah tanfidhiyyah adalah melaksanakan undang-undang. Negara dalam melakukan kebijaksanaan baik yang berhubungan dengan dalam negeri maupun yang menyangkut dengan hubungan sesama negara (Muhammad, 2014: 177). Persoalan terkait pengelolaan sumber daya pertambangan alam melalui peraturan-perundang-undangan haruslah sesuai dengan kaidah sumber hukum fikih siyasah dusturiyah yakni al-quran dan sunnah Nabi Muhammad SAW serta kebijakan ulil amri dan kebiasaaan adat suatu negara yang tidak melanggar aturan syariat, kemudian juga dijelaskan dalam Al-Qur'an (QS Annisa' ayat: 58)

"Sesungguhnya Allah menyuruh kamu menyampaikan amanat kepada yang berhak menerimanya, dan (menyuruh kamu) apabila menetapkan hukum di antara manusia supaya kamu menetapkan dengan adil. Sesungouhnya Allah memberi pengajaran yang sebaik-baiknya kepadamu. Sesungguhnya Allah adalah Maha mendengar lagi Maha melihat".

Berdasarkan uraian di atas dapat dilihat bahwa Pemerintah Kabupaten Dharmasraya sudah mengeluarkan Peraturan Daerah Nomor 19 Tahun 2007 tentang Pengolahan dan Pengusahaan Pertambangan dan Energi. Serta diperjelas secara terperinci didalam Pasal 5 Ayat (1) "usaha pertambangan umum baru dapat dijalankan sebagaimana mestinya apabila telah di keluarkannya Kuasa Pertambangan (KP), Kontrak Karya (KK), Perjanjian Karya Pengusahaan Pertambangan Batubara (PKP2B),Wilayah Pertambangan Rakyat (WPR), Surat Izin Pertambangan Rakyat (SIPR) serta Surat Izin Pertambangan Daerah (SIPD) dari Bupati" sebagai landasan legal untuk melakukan kegiatan penambangan yang sah. Berdasarkan Peraturan ini, pertambangan dapat dilakukan apabila sudah memenuhi syarat dan ketentuan yang telah mencukupi kelengkapan data.Peraturan yang telah dibuat oleh pemerintah ini masih belum terjalankan karena, masih banyak penambang liar atau penambang illegal yang memanfaatkan lahan untuk dijadikan tempat usaha pertambangan. Kegiatan pertambangan iniberpengaruh sekali bagi masyarakat sehingga berdampak buruk terhadap aliran sungai.

\section{METODE PENELITIAN}


Dalam Penelitian ini penulis menggunakan pendekatan kualitatif (kualitatif research). Jenis penelitian ini adalah penelitian lapangan (Field Research) yaitu suatu penelitian yang mengungkapkan dan menggambarkan kejadian-kejadian, fenomena data-data yang terjadi di lapangan sebagaimana adanya dengan kenyataan yang sebenarnya dimana penelitian dilakukan.

\section{HASIL DAN PEMBAHASAN}

\section{Gambaran Umum Kabupaten Dharmasraya}

Kabupaten Dharmasraya adalah salah satu Kabupaten di provinsi Sumatra Barat, pada kawasan ini dahulunya pernah menjadi ibu kota dan pusat pemerintahan kerajaan melayu. Ibu kota Kabupaten Dharmasraya adalah pulau punjung Kabupaten ini dibentuk berdasarkan undang-undang nomor 38 tahun 2003 dan merupakan pemekaran dari Kabupaten Sijunjung. Kabupaten Dharmasraya dikenal juga dengan sebutan ranah cati nan tigo. Nama Kabupaten Ini diambil dari manuskrip yang terdapat pada Prasasti Padang Roco dimana pada prasasti itu disebutkan. Dharmasraya disebut sebagai Ibu Kota dari kerajaan melayu waktu itu. Kerajaan ini muncul setelah kejatuhan kerajaan sriwijaya pada abad 13-14, dimana daerah kekuasaan kerajaan ini merupakan wilayah kekuasaan kerajaan sriwijaya sebelumnya, yaitu mulai dari semenanjung malaya hingga sumatra. Sebelumnya, yang dibentuk berdasarkan undangundang nomor 38 tahun 2003 tentang pembentukan Kabupaten Dharmasraya, Kabupaten Solok Selatan dan Kabupaten Pasaman Barat di Provinsi Sumatra Barat, dan diresmikan pada tanggal 7 januari 2004.

Secara geografi Kabupaten Dharmasraya berada di ujung Tenggara Provinsi Sumatra Barat, dengan topografi daerah bervariasi antara berbukit, bergelombang, dan datar dengan variasi ketinggian dari $100 \mathrm{M}-1.500 \mathrm{M}$ di atas dermukaan laut. Sebagian besar jenis Tanah Di Kabupaten Geografis. Kabupaten ini berada di persimpangan Jalur Lintas Sumatra yang menghubungkan antara Padang, Pekanbaru, hingga Jambi. Dharmasraya berjenis podzolik merah kuning. Penggunaan lahan yang didominasi untuk peruntukan hutan hujan tropik seluas 133.186 Ha (44,98 \%) dan Lahan Perkebunan Seluas 118.803 Ha (40,12 \%) sedangkan untuk penggunaan lain sebesar $(14.90 \%)$. Suhu udara di kabupaten ini berkisar antara $21^{\circ} \mathrm{C}-$ $33^{\circ} \mathrm{C}$ dengan rata-rata hari hujan 14.35 hari per bulan dan rata-rata curah hujan $265,36 \mathrm{~mm}$ per bulan

\section{Kendala Yang Dihadapi Pemerintah Kabupaten Dharmasraya Dalam Mengatasi Usaha Pertambangan Dan Energi Ilegal}

Adapun kendala yang dihadapi pemerintah daerah Kabupaten Dharmasraya dalam mengatasi usaha pertambangan emas ilegal ini sebagai berikut:

a. Masyarakat tidak mengetahui tata cara menambang dengan baik dan benar, sehingga berakibatkan kepada lingkungan sekitar. Hal ini didasarkan wawancara dengan Kepala Bagian Hukum Kantor Bupati Kabupaten Dharmasraya Bapak Hendra, S.H., MSi, terkait dengan kendala yang dihadapi pemerintah Kabupaten Dharmasraya dalam mengatasi usaha pertambangan dan energi ilegal, pada prinsipnya menyikapi pertambangan ini kami telah mengeluarkan Peraturan Daerah, dimana peraturan ini menjadi pedoman untuk 
menjalankan usaha pertambangan dengan legal. Dengan adanya Peraturan Bupati ini bisa dibilang berhasil mengurangi intensitas pertambangan emas ilegal selama 6 bulan, tetapi kendala yang dihadapi pemerintah saat ini karena masih banyak masyarakat yang tidak mengindahkan peraturan yang dibuat oleh pemerintah ini. Peraturan Daerah ini telah di Sosialisasikan kepada seluruh wali Nagari yang ada di Kabupaten Dharmasraya, maupun setiap ada sosialisasi hukum selalu menerangkan peraturan tersebut. Penegakan peraturan tersebut memang banyak permasalahan dari masyarakat karena masyarakat tidak mau mengikuti prosedur yang telah ditetapkan oleh pemerintah. Sedangkan pemerintah telah membuat beberapa ketentuan yang seharusnya ada didalam menjalankan usaha pertambangan. Masyarakat banyak melakukan penambangan ilegal dikarenakan mereka tidak mau urusannya berbelit-belit dan masyarakat lebih memilih melangsungkan usaha pertambangan dengan kelompoknya sendiri. Kendala yang dihadapi pemerintah ketika masyarakat tidak tau tata cara menambang dengan baik dan benar, hingga nanti lingkungan sekitar akan tercemar. Namun bagaimanapun penegakan aturan harus ditegakkan dengan memberhetikan penambangan ilegal tersebut sesuai aturan yang berlaku, yang mana Peraturan Daerah tersebut telah disepakati oleh pihak-pihak terkait. Pemerintah sendiri memang dalam Peraturan Daerah tersebut apabila ditemukan pelanggaran akan ditindak lanjuti oleh Satpol PP, akan tetapi dengan luasnya Kabupaten Dharmasraya tidak bisa terkontrol secara keseluruhan, maka butuh tindakan represif dan preventif dari masing-masing Wali Nagari di Kabupaten Dharmasraya, dan tidak seluruh Wali Nagari juga menindak lanjuti peraturan ini. Peraturan Daerah ini sulit untuk ditetapakan atau tidak efektif karena budaya cultur masyarakat yang susah dirubah, walaupun untuk ketentraman mereka sendiri, pertambangan ilegal masih banyak dilakukan didaerah atau ditempat wilayah tanahnya sendiri maupun tempat umum. Upaya dari pemerintah saat ini sedang merancang untuk menindaklanjutan Peraturan Daerah tersebut (Wawancara dengan Kepala Bagian Hukum Kantor Bupati Kabupaten Dharmasraya Bapak Hendra, S.H., MSi, tanggal 20 Februari 2020, pukul 10.54 WIB).

b. Sosialisasi yang dilakukan tidak secara menyeluruh, dan perangkat Nagari tidak menyampaikan secara langsung kepada masyarakatnya. Hal ini didasarkan wawancara dengan Kepala Penataan dan Penegakan Hukum Dinas Lingkungan Hidup Bapak Dian Candra Ardhani, ST,. MSi terkait dengan lingkungan hidup. Undang-undang yang mengatur tentang pertambangan itu adalah Undang-undang nomor 4 tahun 2009, dimana mekanismenya itu lagi diatur dalam peraturan pemerintah tentang wilayah penerbitan pertambangan. Didalam prosedur operasional pertambangan tahapannya adalah harus mendapatkan wilayah pertambanagn dulu,wilayah pertambangan terbagi menjadi tiga yaitu wilayah usaha pertambangan, wilayah pertambangan lain, wilayah pencadangan pertambangan. Wilayah yang bisa diusahakan itu adalah wilayah usaha pertambangan dan wilayah pertambangan rakyat. Setelah mendapatkan wilayah pertambangan dari instansi pertambangan maka selanjutnya harus bisa mendapatkan IUP eksplorasi yaitu hak yang diberikan oleh pemerintah kepada pelaku rencana kegiatan untuk mengkaji lebih dalam terkait usahanya. Jadi izin IUP eksplorasi ini bisa dapat melakukan pengeboran, 
melakukan peneliti eksplorasi, dan setelah itu dinamakan dokumen lingkungan. Dokumen lingkungan itu terkait dengan besarnya kegiatan, ada yang tingkatannya AMDAL dan dokumen UKLUPL. Setelah itu disusun maka dalam rangka mendapatkan IUP produksi dalam rangka mengambil hasil dan menjualnya, dalam rangka itu persyaratan Undangundang Nomor 32 tahun 2009, ada namanya izin lingkungan yang skupnya Kabupaten Dharmasraya. Dalam pertambangan harus ada mekanisme pertambangan harus memenuhi ketentuan-ketentuan komitmen yang ada didalam dokumen lingkungan. Dalam pengawasan sektor pertambangan itu bagaimana dalam mengimplementasikan dukumen lingkungannya dari Dinas Lingkungan Hidup. Setelah melaksanakan penambangan, maka akan ada pengawasan dan pelaporan setiap satu semester sekali mengenai laporan pengelolaan pengendalian pencemaran udara, air, kerusakan lahannya. Pengawas lingkunga hidup melakukan pengawasan berdasarkan komitmennya didalam dokumen pertemuan. Wewenang pengawasan melihat tahapan-tahapan untuk melalukan pembinaan seperti teguran terulis, paksaan pemerintah dan sebagainya. Dalam penerapan aturan untuk usaha pertambangan dimulai dari tingkatan aturan seperti Undang-undang Dasar, Undang-undang, Peraturan Pemerintah, Peraturan Mentri, Peraturan Daerah, maka peraturan tentang usaha pertambangan ini sudah ada pedoman untuk mengawasi masyarakat dalam menjalankan usaha pertambangan. Domain pengawasan itu adalah kegiatan atau usaha yang sudah memiliki izin lingkungan. Dompeng adalah kegiatan usaha pertambangan tanpa izin ilegal yang melanggar Undang-Undang. Pemerintah Daerah dalam sekup keterlibatan dalam pengolahan dinamakan pejabat penyidik pegawai negri sipil lingkungan hidup, yang bisa masuk kedalam ranah hukum. Dinas Lingkungan Hidup juga melakukan sosialisasi kepada masyarakat untuk tidak menambang dengan bahan merkuri dan masin dompeng. Kendala yang dihadapi oleh Dinas Lingkungan Hidup yaitu plang-plang yang dibuat oleh Dinas Lingkungan Hidup dirusak oleh oknum yang tidk bertanggung jawab dan tidak ada yang mengindahkan sosialisasi yang disampaikan oleh Dinas Lingkungan Hidup (Wawancara dengan Kepala Penataan dan Penegakan Hukum Dinas Lingkungan Hidup Bapak Dian Candra Ardhani, ST,. MSi, tanggal 20 februari 2020, pukul 13.00 WIB).

c. Masyarakat tidak bisa menghentikan kegiatan usaha pertambangan yang merugikan warga sekitar daerah aliran sungai. Hal ini didasarkan wawancara dengan Ibu Ezi, beliau mengatakan bahwa terkait dengan peraturan yang mengatur tentang pertambangan yang dilakukan secara ilegal disekitar tepian sungai batang hari, pengetahuan saya mengenai pertambangan ini sangat merusak lingkungan dan sebagai orang tua saya sangat takut terhadap anak-anak pergi ke tepian batang hari itu, tanggapan saya pertambangan dalam menggunakan mesin dompeng banyak sekali kerusakan yang ditimbulkan disekitar daerah kami, baik dari segi bunyi mesin yang keras dan bisa berupaya longsor dipinggir sungai dekat kami. Reaksi masyarakat kurang setuju dan banyak yang merasa risih, akan adanya usaha dompeng ini. Kegiatan usaha dompeng di daerah saya ini kira-kira sudah berjalan 7 bulanan ini, karena saya melihat razia untuk mesin dompeng ini tidak ada dan kurang berjalan dari pemerintah. Dampak yang ditimbulkan sangat berpengaruh, seperti sungai menjadi keruh, sungai menjadi dalam, dan air jenih yang dulu bersih sekarang tidak ada lagi, saya pribadi sangat kecewa akan hal ini, kelompok yang melakukan usaha dompeng ada 3 kelompok, kemaren ada empat kelompok dan yang itu sudah berhenti. Pesan saya kepada pemerintah supaya kasus pertambangan ilegal ini cepat diatasi dan ditindak lanjuti, dam kepada pedompeng liar agar ingin tetap melaksanakan usaha 
tambangnya harus sesuai prosedur yang berlaku supaya tidak merugikan kami semua (Wawancara denganmasyarakat Ibuk Ezi, tanggal 24 februari 2020, pukul 15.05 WIB).

d. Masyarakat penambang tidak mau mengikuti prosedur yang telah ditetapkan karena, penambang ilegal tidak mengetahui langsung tentang sosialisasi yang dilakukan Pemerintah Daerah atau Perangkatnya. Hal ini didasarkan wawancara dengan salah satu pendompeng Bapak Afrizal yang mengatakan, saya sudah melakukan aktivitas dompeng ini sekitar empat tahun sudah, dalam dompeng ini saya bekerja harinya tidak menentu dilihat dari kondisi dan cuacanya, kalau airnya dalam itu tidak bisa dilakukan, waktu yang sering saya lakukan sekitar pukul 9 pagi sampai pukul 4 sore. Kegiatan saya ini tidak diketahui oleh pemerintah, jika diketahui mungkin kami akan di tegur karena saya tau ini dilarang oleh pemerintah. Pungutan yang saya kasih hanya untuk pemuda saja, kalau soal peraturan itu saya tidak mengetahui karena saya tidak pernah mendengar sosialisasi dari pemerintahnya sendiri, yang ada saya dengar hanya omongan dari orang lain yaitu dari mulut ke mulut (Wawancara dengan penambang emas ilegal Bapak Afrizal, tanggal 09 Maret 2020, pukul 11.29 WIB).

Sebagai pedoman masyarakat dalam membuka usaha pertambangan yang legal sesuai aturan yang berlaku, Pemerintah Daerah telah membuat Peraturan Daerah Kabupaten Dharmasraya Nomor 19 tahun 2007 tentang pengolahan dan pengusahaan pertambangan dan energi. Untuk tercapainya kesehjateraan masyarakat, masayarakat dapat mengikuti tata cara atau langkah yang telah dibuat oleh Pemerintah Daerah agar kegiatan usaha pertambangan dapat dimanfaatkan dengan baik supaya warga sekitar aliran sungai tidak merasa resah atas kegiatan pertambangan itu dan mereka juga tidak khawatir akan dampak yang ditimbulkan. Pasal tersebut sudah menjelaskan tentang prosedur pertambangan dari tahap awal sampai tahap akhir agar tidak menyimpang sesuai aturan yang berlaku. Dengan demikian penulis dapat melihat bahwa kendala yang dihadapi pemerintah Kabupaten Dharmasraya dalam mengatasi usaha pertambangan dan energi ilegal ini, karena tidak adanya peraturan Nagari yang mengatur tentang dalam menjalakam usaha pertambangan, kurangnya sosialiasi dari pemerintah tentang tata cara menambang dengan prosedur yang ditetapkan sehingga masyarakat tidak memahami bagaimana prosedur penambangan dengan baik dan benar, kurangnya pengetahuan masyarakat tentang aturan yang dibuat pemerintah, kemudian tidak adanya upaya tindak lanjut dari pemerintah dalam menangani permasalahan pertambangan ilegal di Kabupaten Dharmasraya, kemudian belum adanya anggaran untuk pembiayaan kegiatan dalam perencanaan dan penetapan wilayah pertambangan.

Dalam pertambangan yang legal setiap penambang yang memenuhi syarat selalu memberikan laporan kepada pemerintah, sedangkan penambang yang ilegal tidak mau mengikuti prosedur yang telah ditetapkan karena prosedur tersebut banyak dan harus dilengkapi jika ingin menambang secara legal. Dinas Lingkungan Hidup juga sudah mensosialisasikan kepada masyarakat cara menambang dengan baik dan benar agar lingkungan tidak tercemar.Usaha yang dilakukan Dinas Lingkungan Hidup tidak merata dan tidak secara keseluruhan dimana sosialisasi tersebut tidak sampai ketelinga masyarakat 
sehingga masyarakat tidak mautau atas kerusakan lingkungan yang diakibatkan oleh usaha pertambangan yang mereka lakukan diberbagai wilayah.

Masyarakat itu sendiri tidak mengetahui akan peraturan yang sudah ada, mereka hanya mengetahui dari mulut ke mulut saja. Jadi mereka melangsung pertambangan tidak dengan prosedur yang sudah ditetapkan pemerintah, kurangnya sosialisasi langsung yang tidak sampai ke masyarakat sekitar, peraturan yang dibuat pemerintah tersebut tidak dipertanggung jawabkan dan tidak ada tanggungan dari pemerintah terhap peraturan yang telah dibuat sehingga mengakibatkan banyaknya masyarakat yang tidak menghiraukan atas peraturan yang telah dibaut pemerintah tersebut.

\section{Pandangan Hukum Tata Negara Islam Perspektif Siyasah Dusturiyah}

Siyasah dusturiyahadalah bagian fiqh siyasah yang membahas masalah perundangundangan negara. Dalam hal ini juga dibahas antara lain konsep-konsep konstitusi (Undangundang Dasar Negara dan sejarah lahirnya perundang-undangan dalam suatu Negara), legislasi (bagaimana cara perumusan undang-undang), lembaga demokrasi dan syura yang merupakan pilar penting dalam perundang-undangan tersebut. Di samping itu, kajian ini juga membahas konsep negara hukum dalam siyasah dan hubungan timbal balik antara pemerintah dan warga negara serta hak-hak warga negara yang wajib dilindungi (Muhammad Iqbal, M.Ag.2007:153).

Kajian perundang-undangan baik itu di tingkat pusat maupun tingkat daerah yang dituangkan dalam bentuk perintah maupun larangan. Salah satunya aturan mengenai kegiatan usaha pertambangan yang terdapat dalam Peraturan Daerah Kabupaten Dharmasraya Nomor 19 Tahun 2007 tentang Pengolahan dan Pengusahaan Pertambangan dan Energi. Dilihat dalam pembagian fiqh siyasah dusturiyah maka Peraturan Daerah Kabupaten Dharmasraya Nomor 19 Tahun 2007 tentang Pengolahan dan Pengusahaan Pertambangan dan Energi termasuk kedalamsiyasah tanfidziyyah, yaitu suatu lembaga eksekutif dalam Islam dinyatakan dengan istilah ulil amri dan dikepalai oleh seorang Amir atau Khalifah. Tugas al- sulthah tanfidhiyyah adalah melaksanakan undang-undang. Negara dalam melakukan kebijaksanaan baik yang berhubungan dengan dalam negeri maupun yang menyangkut dengan hubungan sesama negara (Muhammad Iqbal, 2014: 177).

Berdasarkan pasal 5, pasal 6, pasal 7 dan pasal 8 peraturan daerah Kabupaten Dharmasraya Nomor 19 Tahun 2007 tentang Pengolahan dan Pengusahaan Pertambangan dan Energi menjelaskan bahwa peraturan tersebut berisi ketentuan-ketentuan berupa surat perizinan,tempat pertambangan sampai izin pertambangan. Dimana peraturan ini buat oleh pemerintah Kabupaten Dharmasraya untuk menjadi pedoman dalam usaha pertambang secara legal. Pertambangan legal harus melakukan upaya yang sudah diatur dalam peraturan tersebut. Maka dari itu penegakan hukum yang diatur harus dipertegas kembali agar masyarakat tidak melanggar.Sebagaimana dijelaskan dalam surah An-nisa ayat 58:

"Sesungguhnya Allah menyuruh kamu menyampaikan amanat kepada yang berhak menerimanya, dan (menyuruh kamu) apabila menetapkan hukum di antara manusia supaya kamu menetapkan dengan adil. Sesungouhnya Allah memberi pengajaran yang sebaik-baiknya kepadamu. Sesungguhnya Allah adalah Maha mendengar lagi Maha melihat".

Menurut penulis ayat ini menjelaskan bahwa Allah memerintahkan kepada para pemimpin untuk menyampaikan amanah kepada rakyatnya dan memutuskan hukum secara adil kepada manusia, serta dapat menyelesaikan suatu perkara sesuai dengan kemampuan 
yang dimiliki. Setiap perbuatan akan selalu dipertanggungjawabkan, pemimpin akan bertindak hati-hati terhadap segala ucapan, tindakan, bahkan peraturan-peraturan yang dibuat. Seorang peminpin juga harus mampu berlaku adil terhadap semua orang tanpa pandang bulu.

Penerapan aturan belum maksimal dilakukan oleh pemerintah itu.Sementara tuntutan menurut Hukum Tata Negara Islam itu setiap yang dibuat itu harus dilaksankan dan harus diterapkan dalam masyarakat.Sesuai dengan konsep siyasah tanfidziyyah karena Peraturan Daerah Kabupaten Dharmasraya Nomor 19 Tahun 2007 Tentang Pengolahan dan Pengusahaan Pertambangan dan Energi ini dibuat untuk kemaslahatan lingkungan sekitar masyarakat dan prosedur pertambangan sesuai yang telah ditentukan pemerintah agar tidak merusak air sungai. Salah satu caranya yaitu menjalankan dan melaksanakan apa yang pemerintah himbau kepadanya. Artinya dalam proses pertambangan masyarakat penambang harus mengikuti prosedur yang sudah ada dan menerapkan dengan baik, serta penambang ilegal. Pemerintah dalam menjalankan tugasnya haruslah memperhatikan masyarakat tentang apa yang dilakukan masyarakatnya, kejadian-kejadian yang ada disekitar masyarakatnya. Oleh karena itu Pemerintah Kabupaten Dharmasraya diharuskan memberikan himbauan dan teguran serta menindak lanjuti setiap pelanggaran demi tercapainya kemaslahatan umat. Kerena peran pemerintah dalam etika kepemimpinan dalam islam yang pokok adalah tanggung jawab. Akan tetapi tanggung jawab disini bukan hanya untuk menyelesaikan tugas saja, tapi untuk mewujudkan kesejahteraan bagi masyarakat.

Dilihat dari kenyataannya pemerintahan kabupaten dharmasraya belum sesuai dengan kriteria pemimpin didalam hukum tata negara Islam dimana kepemimpinanya belum amanah dalam menyampaikan peraturan yang dibuat untuk masyarakat jalankan. Misalnya saja dalam mensosialisasikan peraturan yang terlah dibuat mengenai pertambangan belum sampai kepada keseluruhan lapisan masyarakat disampaikan sehingga masyarkat tidak mengetahui atas kebijakan yang telah dibuat oleh pemerintah. Kinerja pemerintahan kabupaten dharmasraya kurang efektif dari segi bersosialisasi dengan masyarakatnya, sedangkan didalam pemerintahan Islam pemimpin itu dianjurkan terjadinya keterbukaan antara pemerintahan dan masyarakatnya sehingga tidak terjadi kesalah-kesalahan ditengah-tengah masyarakat bahkan dalam islam dimintak pertanggung jawaban atas apa yang dipimpin oleh pemimpin tersebut

Berdasarkan wawancara yang telah penulis lakukan, penulis berkesimpulan bahwa mengenai ketentuan terhadap usaha pertambangan dompeng ilegal dalam Peraturan Daerah Kabupaten Dharmasraya Nomor 19 Tahun 2007 Tentang Pengolahan dan Pengusahaan Pertambangan dan Energi telah sesuai dengan kajian siyasah tanfidziyyah. Siyasah tanfidziyyah telah menjelaskan tentang peraturan perundang-undangan. Dimana konsep tersebut bahwa penerapan syariat islam untuk mentaati aturan yang telah dibuat oleh pemerintah. Tujuan aturan tersebut untuk kemaslahatan masyarakat. Oleh karena masyarakat harus mengamalkan peraturan perundang-undangan salah satunya Peraturan Daerah Kabupaten Dharmasraya Nomor 19 Tahun 2007 Tentang Pengolahan dan Pengusahaan Pertambangan dan Energi. Namun pada kenyataannya yang terjadi di Kabupaten Dharmasraya masih banyak masyarakat dalam menjalankan usaha pertambangan emas ilegal yang menggunakan mesin 
dompeng. Artinya masyarakat itu tidak taat kepada peraturan yang telah dibuat oleh pimpinannya atau pemerintahnya.

\section{KESIMPULAN}

Penelitian yang penulis lakukan ditemukan bahwa, Implementasi Peraturan Daerah Kabupaten Dharmasraya Nomor 19 Tahun 2007 tentang pengolahan dan pengusahaan pertambangan dan energi tidak terlaksana dengan baik. Kendala yang dihadapi pemerintah adalah ketika masyarakat mengetahui peraturan yang telah dibuat, dan mereka para penambang liar tidak mengindahkan sosialisasi yang disampaikan Pemerintah Daerah. Kedua pandangansiyasah dusturiyah terhadap implementasi Peraturan Daerah Kabupaten Dharmasraya nomor 19 tahun 2007 dimana kinerja kepemimpinan yang belum memiliki sifat- sifat seorang pemimpin belum dimiliki secara keseluruhan.

\section{REFERENSI}

Abdullah, R. 2000. Pelaksanaan Otonomi Luas Dan Isu Federalisme Sebagai Suatu Alternatif, Jakarta: PT Raja Grafindo Persada

Djazuli, A. 2007.Fiqih Siyasah Implementasi Kemaslahatan Umat Dalam

Rambu-Rambu Syariah. Jakarta: Prenada Media Group.

Herimanto dan Wirano, 2016. Ilmu Budaya dan Budaya Dasar. Jakarta: Bumi Aksara

Iqbal, M. 2014. Konstektualisasi Doktrin Politik Islam. Jakarta. Prenadamedia

Jubair Situmorang 2012. Politik Ketatanegaraan Dalam Islam (Siyasah Dusturiyah. Bandung: Pustaka Setia

Pipin Syarif dan Dedeh Jubaidah , 2012 Ilmu Perundang-Undangan, Bandung: Cv Pustaka Setia

Situmorang J. 2012. Politik Ketatanegaraan Dalam Islam (Siyasah Dusturiyah, Bandung: Pustaka Setia

Undang-undang Nomor 23 Tahun 2014

Peraturan Daerah Kabupaten Dharmasraya Nomor 19 Tahun 2007 tentang Pengolahan Pengusahaan Pertambangan dan Energi 